\title{
Transformation of Production Organization of Dusung based Nutmeg Plantation (Case Study of Industrial and Farmers' Partnership in Hila Village, Moluccas Province)
}

\author{
Jeter Donald Siwalette \\ Postgraduate, Department of Rural Sociology, Faculty of Agriculture, \\ Brawijaya University, Indonesia \\ Department of Agricultural Socio Economic, Faculty of Agriculture, \\ Pattimura University. Ambon, Indonesia \\ Kliwon Hidayat \\ Department of Rural Sociology, Faculty of Agriculture, \\ Brawijaya University, Indonesia \\ Edi Dwi Cahyono \\ Department of Rural Sociology, Faculty of Agriculture, \\ Brawijaya University, Indonesia \\ Mangku Purnomo \\ Department of Rural Sociology, Faculty of Agriculture, \\ Brawijaya University, Indonesia
}

\begin{abstract}
This paper provides new information that is rarely studied, related to the organization transformation of dusung based nutmeg plantation production. This research is aimed to know the transformation of production organization of nutmeg plantation based on dusung because partnership between community of nutmeg farmer and plantation industry in Hila village. The method used is qualitative research, using case study strategy. The sample was determined by purposive sampling with snowball technique. To obtain detailed data, informants and key informants are interviewed, ranging from village heads, community leaders, and village government staff, who knew the dusung. Furthermore, key informants who knew the plantation industry are company leaders, production managers, general managers, employees as informants who know the presence of industry and farmers who collaborate with the industry. Secondary data is obtained from documents of research results and industry progress reports. The result of the research shows that the presence of industry causes transformation of production organization, land resource management, technology and technique of nutmeg cultivation, production relation and orientation of nutmeg farmer based on dusung to organization of industrial production. This study is expected to contribute to other researchers who examine the typical agricultural production organization in a region due to the infiltration of the plantation industry. It also provide information that by the entry of industry in a region, the culture of local communities that become the primary source of income society is expected not to be reduced.
\end{abstract}

Keywords: nutmeg, industry, transformation, production organization, dusung 
Siwalette, J. D., Hidayat, K., Cahyono, E. D., \& Purnomo, M. (2018). Transformation of Production Organization of Dusung based Nutmeg Plantation (Case Study of Industrial and Farmers' Partnership in Hila Village, Moluccas Province). Advances in Social Sciences Research Journal, 5(3) 23-36.

\section{INTRODUCTION}

The nutmeg plant (Myristica fragrans houtt) is a native plant of Moluccas Province, Indonesia, which has historical and economic value. Where nutmegs became a major trading commodity since the 17th century with parallel popularity to the Silk Road in China (Purseglove et al., 1995; Winn, 2010). Rumphius (1743) stated that God has given precious wealth to the Moluccan Society in the form of Clove and Nutmeg. Nutmeg is known as one of spice plants that has high economic value and multipurpose because every part of plant can be utilized as industrial raw material, spices, farfum, cosmetics and medicine to date (Leela, 2008; Sanghai et al, 2011; Jangit et al., 2014). Indonesia is one of the largest nutmeg producers in the world (Ruhnayat \& Martini, 2015). In 2014, Indonesia is the largest country in the world as a nutmeg exporter, after Guatemala (ITC, 2015).

Nutmeg plants can grow well in the tropics until more than 100 years old. It also grow in America, Asia and Africa (Jaiswal \& Singh, 2009). In 2015, Indonesia produced approximately 26 types of essential oil from nutmeg and exported 339 tons with a value of 14,456 USD (Ma'mun, 2013). While the seeds are exported annually around 10,000 tons to the United States, Japan, Europe and India for pharmaceutical and food flavoring (Calliste et al, 2010).

Nutmeg that is managed based on dusung has an increasing production in Moluccas, especially on the islands of Ambon, Lease and Seram every year since the 1990s (Gils \& Cox, 1994; Sirappa \& Susanto, 2015). In 2011, nutmeg production reached 2,700 tons. This production increased to 4,307 tons in 2012, 4410 tons in 2013, and rising to 4,410 tons in 2013 (Central Bureau of Statistics of Moluccas, 2013). The quantity of nutmeg every year has increased but its quality is deficient. The disadvantages are not hygienic, the water content is high and contains aflatoxin that exceeds the maximum limit. The low quality, causing problems in marketing that affect the income and welfare of farmers (Provincial Agriculture Office of Moluccas, 2012).

Farmers in Moluccas cultivate nutmegs with a dusung based farming system that is a polyculture production system with agricultural crops, plantations and forestry and livestock trees in one territory for food and economic needs (Zener, 1994; Barton, 2012; Salampessy et al., 2017). The production organization is communally owned by a kinship group (matarumah) and some are managed by each individual following hereditary cultures (Kaya, et al 2002, Matinahoru, 2014). Dusung is an "intangible" asset in Moluccas belonging to indigenous knowledge and indigenous technology of society (Matinahoru, 2009: 2011). In contrast to agroforestry elsewhere, dusung is closely related to the social structure of the community and local kinship, therefore to know the system of farm-based dusung can not be separated with the culture of society.

The transformation of dusung is relatively slow even though the colonial had introduced modern management, which is practically contrary to the management style of the dusung. The pattern of modern management based on private ownership is not necessarily applicable in the dusung ownership system, so it is very difficult to build a large plantation industry as in other parts of Indonesia. Since colonial times by the Portuguese, Dutch and Japanese until today, there is only one colonial inheritance nutmeg plantation in the Banda archipelago, Moluccas (Lape, 2000). Meanwhile, global capitalist penetration has undergone transformation from control through military and trade so that culture shifts to standardization through certification and other forms of monopoly (Robinson, 2007; Tausch, 2012). This paper will focus on how the system of dusung as a model of local-based natural resource management. One of the investors came from the Netherlands namely PT Ollop established a plantation industry based nutmeg dusung in Hila Village Leihitu District, Central Moluccas Indonesia. 
This fact is interesting to be studied in more comprehensive and in-depth related to the presence of industry from the Netherlands in partnership with the community of nutmeg dusung-based farmers, because research on the presence of pala-based plantation industry to date has not been studied. Based on existing social information and facts, this study aims to find out the organization of nutmeg production, production relations and farmer orientation to manage it based on dusung and to know the implications of the presence of PT Ollop as an outside nutmeg plantation industry to introduce a new production organization which implies the transformation of production organization, production and orientation of nutmeg dusungbased farmers.

\section{METHOD}

This research uses a qualitative approach with case study strategy, because it aims to understand the organization of nutmeg production based on dusung transformed following plantation industry production organization, production relation and farmer orientation. Location was determinated deliberately. It is in in Hila Village, Leihitu District, Central Moluccas District, Moluccas, Indonesia. As shown in Figure 1. The determination of this village is based on several considerations, they are 1) the people of Hila village from the past to the present practice of farming system dusung, 2) since 2006 in this village, one of the investors from the Netherlands, PT Ollop, build a nutmeg plantation industry and collaborate with local farmers.

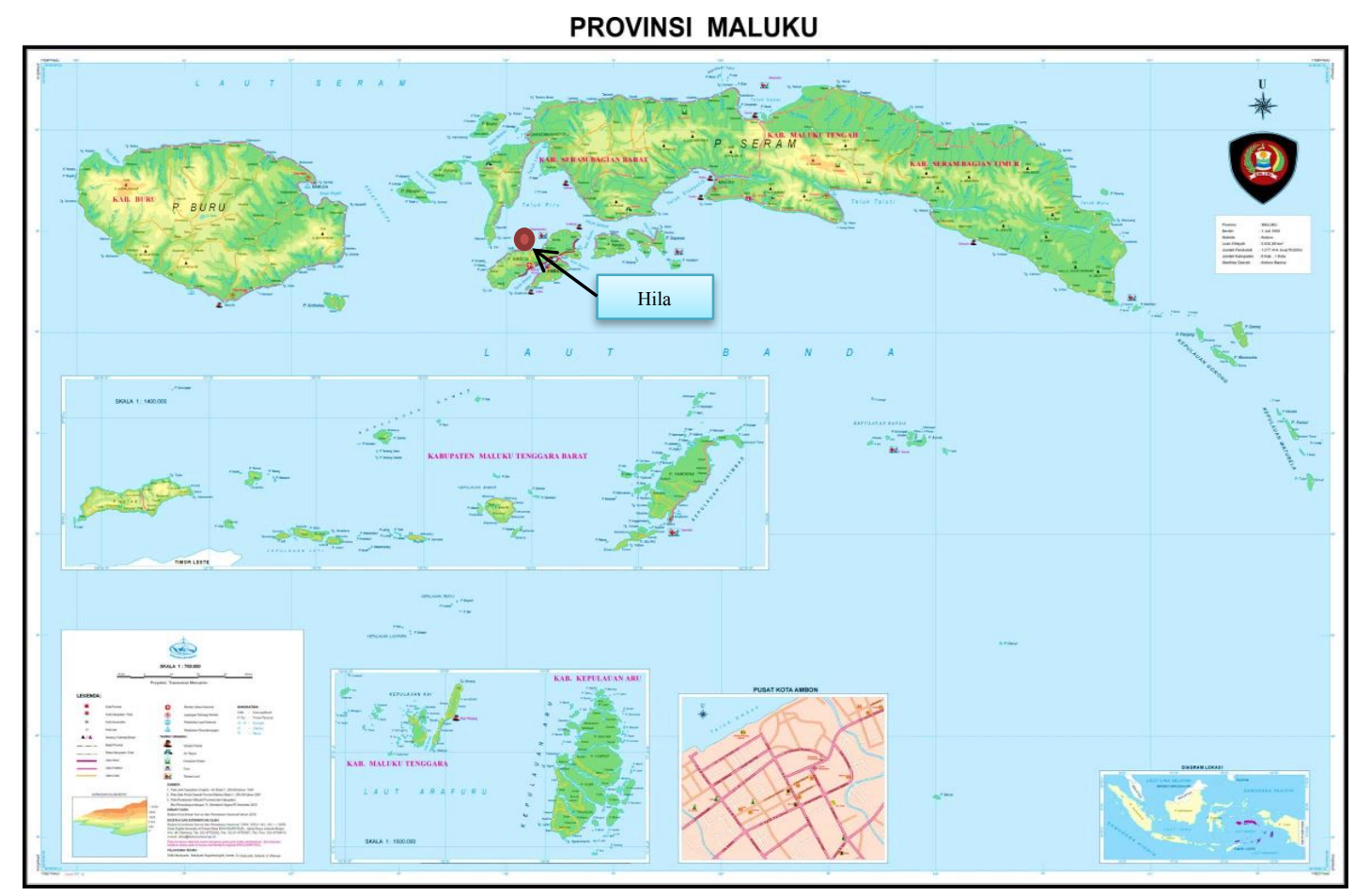

Figure 1. The Territory of Moluccas Province, Indonesia (Source: Moluccas in Figures, 2015)

The data sources in this study consist of key informants and usual informants. Key informants consist of local community members, ie village heads, community leaders, and village government staff and from the nutmeg plantation industry, which are owners and managers, general managers and production managers. The first key informant determination was made to the village head and the owner of the company, PT Ollop. It is done intentionally on the basis that they know and understand the social processes that occur between the nutmeg industry company and the local nutmeg community. Another key informant was selected using snowballs in order to obtain more detailed data (Corbin \& Strauss, 2007; Creswell, 2013). 
Siwalette, J. D., Hidayat, K., Cahyono, E. D., \& Purnomo, M. (2018). Transformation of Production Organization of Dusung based Nutmeg Plantation (Case Study of Industrial and Farmers' Partnership in Hila Village, Moluccas Province). Advances in Social Sciences Research Journal, 5(3) 23-36.

The data were collected by using several techniques, such as 1) Document of important information from village like village monograph and company progress report every year, 2) observation or observation of direct participation with farmer and company side, and (3) Indepth interview with key informant and other informants. Documents are collected from companies, village offices and other relevant sources. Participatory observation was conducted for 2 months (August-September 2016). The objects observed are the activities of the company and dusung of company's partner farmers and non-partners.

The process of data analysis is done during the research process, by the way the researcher checks repeatedly, if the answer given does not match the fact that happened, so the researcher repeated the questions when interviewed or when the researchers met in different place to test the truth of data be delivered. In addition, researchers conducted direct observations in the field to record the problems related to the problem under study. Furthermore, researchers reduce data by focusing on data collected from records that have been examined. The researcher discarded unnecessary data before drawing conclusions and verifying data with key informants, and then analyzed again to draw conclusions to get results from the research. Data analysis was performed using interactive methods (Miles et al, 2014)

\section{RESULTS}

\section{RESULTS AND DISCUSSION}

\section{Engineering of Land ownership status}

Prior to the infiltration of PT Ollop as a plantation industry and established partnerships with farmers in Hila Village, Leihitu Sub-district of Central Moluccas District, land ownership management (dusung) based on geonological kinship (matarumah). Based on the results of the research there are four groups of kinship (matarumah) namely, a) matarumah Lating called Nustapi, b) matarumah Elly called Totohatu, c) matarumah Ollong called Pati Tuban and d) matarumah Ukututelu called Matitauwe. Each matarumah (kinship group) has land (dusung) with different area. Each appoints a son (head of the dati), whose job is to distribute the dusung as a farming asset for all unmarried sons and daughters and to keep them under control, except for the common good. The term agricultural land for the people of Moluccas is known by the name dusung which means Land of Moluccas.

A farmer has a dusung in Hila Village for two reasons: 1) inheritance from parents, to boys on the grounds that they will inherit the clan (fam) in matarumahfollowing patrilineal descendants, girls do not receive inheritance but have the right to use the shirt for the sake of gardening for the brother's approval. 2) Ownership of individual beads, because of the efforts of a boy. If a man has married, then the individual or head of the family opens the primary forest to be used as a dusung. However, the opening of primary land should be the approval of the tribal chief (head dati) as the holder of the rights to the coveted area where the primary forest is located.

The area of farmer's nutmeg in Hila village ranges from 1-3 Ha with the average of land ownership of nutmeg owned by farmer is only $1 \mathrm{Ha}$. This wide variety of area is due to the opening of primary forest land to be used as dusung, the farmer is faced with the problem of capital and physical strength to do it. Whereas the inheritance of the communally owned heritage depends on what has been done by their predecessors.

The infiltration of PT Ollop to Moluccas specifically Ambon City, originally moved as an exporter of spices in the form of cloves and nutmeg. Where only buy from farmers and sell them to the regions in Europe, such as, the Netherlands and France. However, due to market requirements, that nutmeg prior to export must have certification or legal feasibility to explain 
that the commodity is safe for consumption, then PT Ollop established its company to process nutmeg in Hila Village. In addition to proces nutmeg before shipment, the certification requirement is to have and manage the nutmeg plantation with the principle of sustainable agriculture, so that the strategy is to partner with the farmers to manage and control the land to meet market standards.

Facts in the field prove that, most of the farmers in Hila village have land because of inheritance and communally owned by matarumah. Indeed there are some nutmeg farmers who own the land individually but it is also controlled by the leader of the kinship group (kepala dati). This external condition is the problem for partnering. Therefore, PT Ollop as the company, utilize village leaders, community leaders and religious figures to influence farmers by providing capital assistance to farmers. The role of the figures in the village and the assistance provided, the farmer responded by consolidating the internal house. Where it is agreed that dusung owned communally are included to partner with PT Ollop.

Based on the agreement, there is a partnership between farmers representing Matarumah and PT Ollop. However, within the contents of contractual agreements between individuals representing the matarumah are contrary to terms and agreements. The only individual who signed the contract to collaborate with PT Ollop collaborate to manage the nutmeg. While other family members, are prohibited from doing activities on the dusung. So that the impact of other family members lose the source of income and ownership of the dusung, as directed by PT Ollop.

\section{Transformation of Technique and Technology of Cultivation of Nutmeg from Traditional System to Industrial Plantation}

Prior to the entry of PT Ollop, farmers cultivated nutmegs ranging from land clearing to postharvest based on the local knowledge possessed by them following the hereditary traditions. Tools used to manage Dusun are axes, machetes, hoes, crowbars, and do not use fertilizers and other chemicals without the input of modern technology. Farmers select seeds following the tradition of their predecessors, using only nutmegs that have grown naturally to be cultivated or by other means of picking nutmeg seeds that have been matured in the trees, then seeded beside the house by utilizing used cans as a medium. After the seeds are large and are well worth moving to a larger area, the farmer brings them to the dusung for planting.

As Junar Olong explains as a nutmeg farmer in Hila Village that:

Prior to the entry of PT Ollop, farmers choose nutmeg seeds to be seeded only following local knowledge they have, namely broken nutmeg or ripe so it is predicted to have high productivity. As shown in Figure 2.

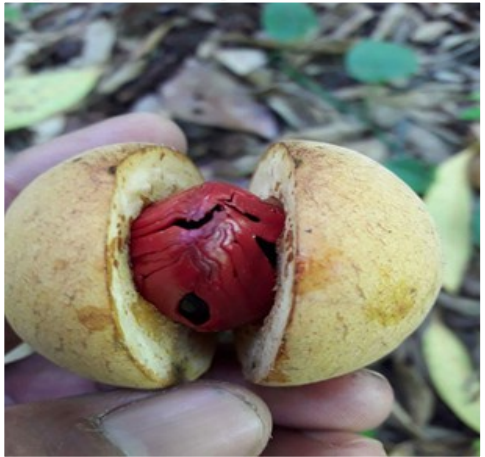

2a

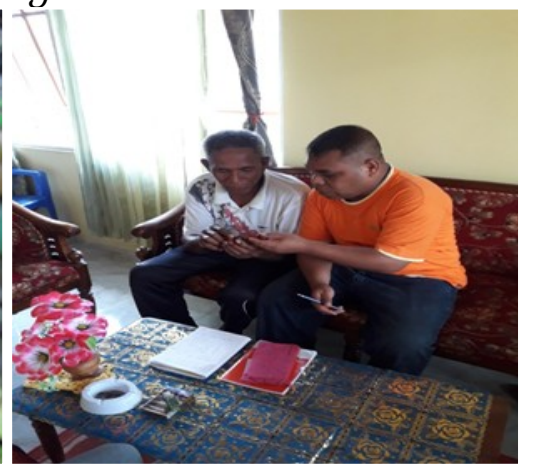

2b

Figure 2. a. Broken nutmeg or ripe nutmeg is requested so that it is predicted to have high productivity, b. A farmer, by the name of Juniar Olong, explains seed selection techniques based on local knowledge. 
The entry of PT Ollop in Hila Village contributes greatly to the community, especially the farmers. Where, providing training to farmers to do nutmeg seed selection in accordance with the standards, must be certified and must be sown in polybags, as shown Figure 3.

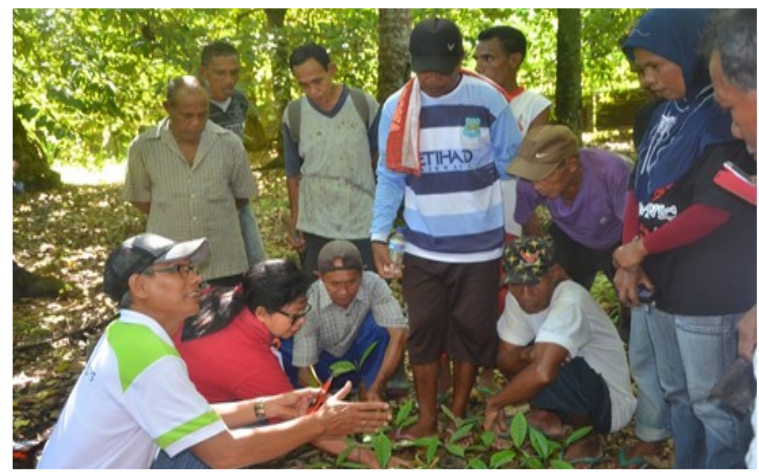

Figure 3. The PT 0llop party trained farmers to select nutmeg seeds

Previous activities that are usually done by farmers are 1) planting done without plant spacing, 2) planting hole following high seed, 3) besides nutmeg that has been planted never done watering, only expect rain, 4) Farmers do not use fertilizer for nutmeg plant, because according to them that the ancestors have prohibited the use of fertilizer. According to farmers dusung has been fertile and if using chemical fertilizers, the plant will produce high but only a season after that the plant will die and the soil that is given fertilizer will not be fertile again. They assume that chemical fertilizers will kill nutrients in the soil.

Nutmeg plants are attacked by pests and diseases, such as; suffered drought on the stem, due to the large number of termites and fungi growing on the nutmeg plants. So farmers do not use chemical drugs to prevent it, but it is overcome with local knowledge, by taking sand along the shore and ash, the rest of the burning is sown to eradicate pests and diseases that attack the plant and it prove itself to overcome the pest and dieases.

The farmers harvest the nutmegs when most of the nutmegs have been yellowed or some of them have been matured with the characteristics of the nutmeg flesh have been broken and visible batter and nutmeg. Other signs are some fruits have fallen to the ground and the shells are black and the nutmeg has been colored red (Figure 2a). However, because of the consumption needs, farmers harvest immature. Farmers harvest by climbing trees and using gala to drop the nutmeg to the ground. Then, we should separate the fruit flesh and seeds that are still wrapped in nutmeg flower taken to be dried or sold.

After harvesting the nutmeg, the farmer bring it to the house to separat between the nutmeg shell and fuli (nutmeg flower). After it is dried by using the hot sun or fogging. Farmers take advantage of the sun when harvest in August-October, but if harvest in April and May together with the rainy season, utilize the sun and assisted with the process of fogging. If using the sun, farmers dry the nutmeg by drying for 3-5 days. The drying is done on the street front of the house or behind the house (Traditional System).

As explained by Muhammad Nurdin Lating from the industry side that:

Before the entry of PT Ollop farmers dry the nutmeg by utilizing sunlight and drying done on the street front of the house or behind the house, so it will not hygienic. As shown in Figure 4. 


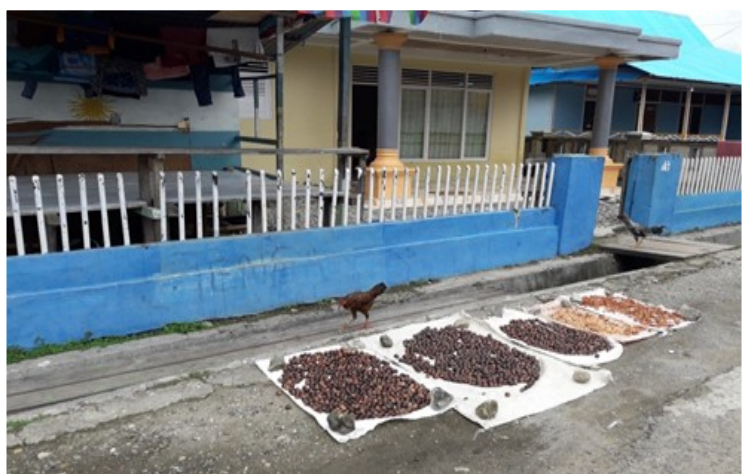

Figure 4. The drying of Nutmeg traditionally on the street front of the house

The presence of plantation companies brings very significant change. The nutmeg is dried in its place (para-para), so it is free from the disruptive animals. This knowledge is not shared by farmers before. As shown in Figure 5.

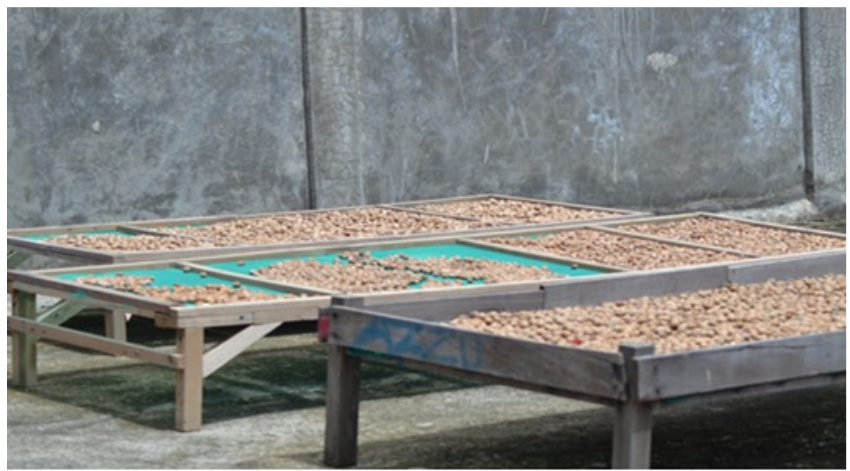

Figure 5. Modern nutmeg drying spot after the entry of industry

The curing process takes 5-7 days, after which nutmeg seeds are separated from the shell by pounding with carved wood, which is fried to ground the nutmeg. The goal is to be able to take the black nutmeg or brownish. After that, farmers put nutmeg in plastic sacks. If large amounts are kept in the bedroom or in the kitchen, but when in small quantities the farmer sells them directly to the trader or the middleman.

After the infiltration of PT Ollop and established partnership relationship. PT Ollop utilizes various experts from several competent institutions including; field extension officer, agriculture officer of Moluccas Province, agricultural officer of Central Moluccas district, academic from Faculty of Agriculture, Pattimura University of Ambon, provide training and assistance to the farmers regularly every month about the technique and technology of nutmeg cultivation based on dusung so that "force" farmers to do transformation from land preparation to post-harvest.

Farmers are also taught for the techniques and equipment used for planting. Farmers are "required", for the land to be prepared following the rules set by PT Ollop, such as: the excavation of the planting hole should be $60 \mathrm{~cm} 3$, after which it is left for one week for the acid soil to disappear and must use organic fertilizer, animal waste. Equipment used by farmers is "required" sterile and uncontaminated, such as; machetes, crowbars, hoes only specifically for nutmeg plants should not be used for other plants. Besides, the process of maintaining the dusung nutmeg should be routine and controlled by the industry with dusung notebook, so farmers are required to weed routinely, clean the parasites in the nutmeg trees, make the flow of water or drainage arrangement in the dusung which is on the steep topography to avoid flood, doing fumigation to prevent nutmeg plants from pests. 
Farmers "are required" to perform the transformation of selecting nutmeg seed before planting. Things to do are: 1) Nutmeg seeds must be selected from trees over the age of 20 years, 2) nutmeg free from disease, 3) taken from parent trees that produce about 3000-4000 seeds per tree. Then, the nutmeg seeds is sown in polybag size $5 \mathrm{~kg}$ and are required to do watering every day. After the seeds are 4-6 months old, then ready to be planted in the dusung. The next process is maintenance for many years and arrive at the process of producing fruit and waiting for harvesting. Harvest time is done when nutmeg is 9 months 10 days or some nutmeg that has been mature in the tree is marked with some yellow nutmeg and has broken. The nutmeg harvest is required to use a bamboo tool whose ends have been designed using a large net (Figure 6), so the process of taking nutmeg does not fall directly to the ground. The process of separating the nutmeg from nutmeg shells still wrapped in flesh and nutmeg, should use a sterile knife.

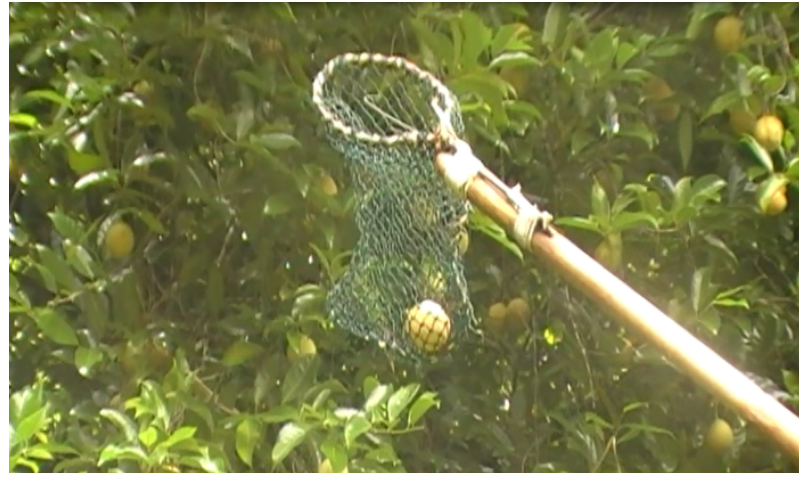

Figure 6. The nutmeg harvest process uses a safe tool to keep the nutmeg from falling to the ground

Post harvest handling is carried out as follows: 1) farmers are required to dry the nutmeg above para-para (Figure 5), 2) Utilizing the hot sun or fumigation (when the rainy season), 3) the drying place should be clean, 4) the drying location should be away from the road raya \pm 20 meters, 4) away from animals and poultry for hygienic products. After that dried nutmeg is stored in a clean burlap sack and stitched with a sterile needle and then stored in a room that is not moist and protected from predators such as rodents, cockroaches, lizards and other annoying animals.

\section{Production Relation}

Before the existence of plantation industry ie PT. Ollop, farmers in Hila Village manages dusung nutmeg by family consisting of father, mother and children. Dad as the main workforce, mothers and children help the work that is considered light like, cleaning the weeds, harvesting and post-harvest that separates the fuli from nutmeg seed. When jobs that require a lot of manpower such as, cleaning the dusung then done in mutual help (masohi culture) and this has been practiced from generation to generation. In addition, at harvest time the nutmeg is usually done jointly by the matarumah group and also involves the neighbor as a culture of sharing (baku bage) which implies that the life of fellow or relatives must share or reciprocity.

After the infiltration of PT Ollop as an industry and established partnerships with farmers, the values of traditional production relations began to erode. This is because farmers are controlled by PT Ollop in accordance with the contents of the contract agreement that, only relate to the individual signing the contract. So that local culture in the form of gotong royong (masohi culture) to clean the dusung and the culture of sharing (baku bage) which means that the life of fellow brother or relatives must share no more practice because the company rules 
are in contract agreement. It prohibits mothers and underage children to work in the dusung. PT Ollop will give sanction if farmers found to employ mothers and children..

\section{Engineering Institutional Marketing}

Prior to establishing a partnership relationship between farmers and PT Ollop. Farmers sell nutmeg to traders in the village, sub district or merchant in Ambon City at the prevailing price in the market. The strategy by PT Ollop for farmers to sell nutmeg to them is, farmers partnered and capitalized to build a cooperative with the aim to buy nutmeg from farmers before being marketed to PT Ollop. In addition, the price of nutmeg nut is higher than the prevailing market price.

Another strategy undertaken by PT Ollop is to utilize key village figures to get farmers to sell nutmeg to Cooperatives and PT Ollop, later on there will be a share of profits after nutmeg is exported, it will be donated for the development of village infrastructure and for the construction of religious infrastructure in the form of mosques and church

\section{Farmer Orientation}

Farmers in the village of Hila are managing nutmegs based on dusung, before the infiltration of PT Ollop as a plantation industry. They are communal-based and among farmers sharing existing natural resources, helping each other of close family in one matarumah or because of neighboring relationships. The orientation of farmers is only to meet the daily food needs and to fund the children's school from elementary level to university level. So in principle the orientation of farmers is for subsistence.

The infiltration of the plantation industry has had a positive impact on farmers. PT Ollop in addition to transforming land tenure management, cultivation technology and nutmeg techniques, also changed the orientation of farmers, by motivating farmers, to not only cultivate for consumption but to increase farmers' income. Farmers are invited to open new land, demolish unproductive nutmeg plants, take care of nutmeg plants for increased production. Introduce banks to save farmers and send their children to higher levels, so that the orientation or actions of farmers have changed, so now farmers' farming activities in Hila Village have been based on efficiency and calculation considerations, no longer referring to custom or tradition. PT Ollop has the hope that the existing natural resources in Hila village, in the form of nutmegs can provide a great deal for them in the future by channeling their children to a higher level as the nation's great change agents. The goal of the school itself is to become a superior human resources to advance the Moluccas region and the Indonesian nation at national and international level (Leasa et al., 2016; Laurens et al., 2018; Gemnafle et al., 2018).

\section{Discussion}

\section{Transformation of Production Organization of Dusung based Nutmeg Plantation}

Transformation is a process of change of form from one form to another, this happens because the external and internal factors that influence so that there is a change through the process repeatedly in the dimension of time sooner or later that impact on the social, economic and cultural changes of society (Codreanu, 2010; Tang, 2011; Vicol et al, 2018).

The results showed that the infiltration of the plantation industry into Hila Village led to transformation of production organization on aspects; 1) Land Ownership Management, 2) Nutmeg Cultivation Techniques include; hatchery, cultivation, land maintenance, harvest time, harvesting and harvesting technology and methods. 3) Marketing Institution, 4) Production Relation, 5) Orientation of farming. In summary, the transformation of the nutmeg plantation 
organization as a result of the presence of the nutmeg plantation industry is shown in the following table.

Table of Transformation of Plantation Production Organization of Nutmeg

\begin{tabular}{|c|c|c|}
\hline \multirow{2}{*}{ Aspect } & \multicolumn{2}{|c|}{ Production Capital and Production Relation } \\
\hline & Traditional & Industry \\
\hline Land ownership management & Communal & Individual \\
\hline $\begin{array}{l}\text { Cultivation Techniques and } \\
\text { Technologies }\end{array}$ & & \\
\hline Land Processing & $\begin{array}{ll}\text { - } & \text { No land selection } \\
\text { - } & \text { Land clearing by } \\
\text { burning } \\
\text { - } & \text { Not doing } \\
& \text { pangajiran } \\
\text { - } & \text { Make a planting } \\
\text { hole following } \\
\text { the experience. }\end{array}$ & $\begin{array}{ll}\text { - } & \text { Land selection: } \\
& \text { suitable for nutmeg } \\
& \text { cultivation } \\
\text { - } & \text { The land should not } \\
& \text { be burned } \\
\text { - } & \text { Pangajiran to set } \\
& \text { spacing } \\
\text { - } & \text { Making a planting } \\
& \text { hole a few days } \\
\text { before planting and } \\
\text { given manure and } \\
\text { hole size } \\
\text { approximately } 60 \\
\text { cm3 }\end{array}$ \\
\hline Seed & $\begin{array}{l}\text { Nature (falling and } \\
\text { growing by itself) Seed in } \\
\text { a used tin }\end{array}$ & $\begin{array}{l}\text { Selection of superior nutmeg } \\
\text { seedlings in polybag } \\
\text { Certificate }\end{array}$ \\
\hline Land Maintenance & Not scheduled & Scheduled with a notebook \\
\hline Harvest time & $\begin{array}{l}\text { Choose an old / ripe fruit: } \\
\text { natural in the tree }\end{array}$ & $\begin{array}{l}\text { The fruit is nine months and } \\
\text { ten days old }\end{array}$ \\
\hline Harvesting Technique & $\begin{array}{l}\text { Climbing Without stairs } \\
\text { and jolok }\end{array}$ & Climb using stairs and jolok \\
\hline Post-harvest & Drying on street and floor & $\begin{array}{l}\text { Dry in the para-para, clean } \\
\text { and safe place from animals / } \\
\text { livestock }\end{array}$ \\
\hline Marketing Institution & The middleman & KUD Organik and PT Ollop \\
\hline Production Relation & One Matarumah & Patron Klen \\
\hline Farmer Orientation & Subsistent & Business \\
\hline
\end{tabular}

\section{Research 2016 in Hila Village, Moluccas}

\section{Land ownership management}

Changes in land ownership from communal to individuals practiced as a result of the partnership led to a change. The socio-economic structure of the countryside is not a stable one, the rise of change can be influenced by the transformation of the organization of production (LaForge et al, 2014). At a time when the new production organization is more dominant, it will change land ownership. Changes in land ownership will move from collective domination to individual domination. The change of land ownership from "right of every person" to utilize the resources of land dusung become "right of individual" entitled to make use of it so that there is inequality of farmer access in control of land resource of dusung. The change of land ownership management gave way to the loss of the culture of the community, the opportunity of differentiation process of social structure, encourage the change of farmers access in getting the income from the resources of the dusung so that then there is a change of farmer's welfare.

\section{Cultivation Techniques and Technologies}

This society is very young in socio-cultural change, due to the influence of technology (Steward, 1995, Elliot, 2006). Technological transformation and community cultivation 
resulting from partnership and introduction of technology cause negative and positive impacts (Fernandes \& Mendes, 2003). Negativity began to erode the local knowledge of society because following the market standard environment of dusung forced adapt to follow the industry culture. Positive as a way to force farmers intensive in dusung. Environment well ordered and produce nutmeg products that are hygienic. Another impact will be changes in the welfare of farmers because the products produced meet market standards will be purchased at high prices.

\section{Marketing Institution}

Before the entry of the industry, farmers are free to sell their crops to any marketing agency, in accordance with the wishes and needs of farmers. The entry of industry as a representation of capitalistic market and dilakukakannya community organizing through a partnership system "forced" farmers sell the results of nutmeg products to a cooperative established by farmers on the initiative of PT Ollop or sell it directly to PT Ollop. On the positive side, farmers earn high incomes and can contribute to rural development, because of the policy of PT Ollop there are some benefits that should be paid to farmers given to development in Hila Village

\section{Production Relation}

Culture gotong royong (masohi) which has long been practiced as a typical farmers in the village of Hila began to erode and transform into patron and client bonds. This is in line with that proposed by Dluhosch \& Horgos, 2008, the presence of an industry will change the way production is followed as well as changes in production relations. This is proven by the farmer having the obligation to run the rules of the company. The working relationship between relatives-family as culture gotong royong (masohi) can not be practiced, Farmers who signed a contract that individually work on the dusung to produce nutmeg for the company's interests, are required to sell nutmeg to the industry, instead reply by PT Ollop as a patron by providing production equipment to farmers and buying nutmeg farmers at a higher price than the market price. As a patron of PT Ollop always shows his interest to the farmer as a client like a father to his son.

\section{Farmer Orientation}

Farmers in Hila Village have been managing the nutmegs following hereditary traditions only to survive under minimal conditions collectively in reciprocal social relationships, with the principle of sustainability. However, after the entry of industry through contractual partnerships intervened by means of training and counseling, as well as pressure structural from industrial side resulted in transformation of farmer orientation. Farmers are motivated to no longer work for minimal needs; food but business-oriented farmers are directed to rejuvenate the crop and open up new land, and this is done by farmers so that there is a transformation to farmers in the village of Hila. This is in line with that put forward by Graeber (2006), the presence of an industry causes a shift in social values in the community. Besides, Rumyantsev (2015) stated that the presence of industry leads to transformation and provide many benefits to farmers.

\section{CONCLUSION}

Prior to the entry of industry, nutmeg plantations based on management and production organization based on kinship (matarumah), communal based land management management, cultivation technology and techniques followed hereditary traditions, kinship-based production relations (matarumah), and farmers orientation only for sub-tension. The presence of PT Ollop as a nutmeg industry and inviting partner farming communities resulted in the transformation of production organizations. Management of dusung ownership is engineered into individual property, production relation between farmer and PT Ollop is client patron's 
relationship, farmer is oriented to business oriented. The presence of industry leads to transformation of production organization, land resource management, technology and cultivation techniques of nutmeg, production relation and orientation of nutmeg growers based on dusung to industrial production organization. This study is expected to contribute to other researchers who examine the typical agricultural production organization in a region due to the infiltration of the plantation industry and provide information that with the entry of industry in a region is expected not to reduce the culture of local communities that become the primary source of income society.

\section{ACKNOWLEDGEMENTS}

The author conveyed many thanks to the Rector of Pattimura University who has given permission to continue doctoral studies and Ministry of Research and Technology of Republic of Indonesia who has provided funding for education to continue studying in Brawijaya University, Malang. Hila Village Community, Village Head, Industry Leader PT Ollop, Community Leader, Industrial Manager PT Ollop, employees and especially farmers who provide information to the researcher so that research can run well. Hopefully what is given becomes able to be useful for the lives of many people.

\section{References}

Badan Pusat Statistik Propinsi Moluccas [Central Bureau of Statistics of Moluccas Province]. (2013). https://moluccas.bps.go.id/ (Access, 25 April 2017).

Barton, H. (2012). The reversed fortunes of sago and rice, Oryza sativa, in the rainforests of Sarawak, Borneo. Quaternary International, 249, 96-104.

Calliste, C., Kozlowski, D., Duroux, J., Champavier, Y., Chulia, A., \& Trouillas, P. (2010). A new antioxidant from wild nutmeg. Food Chem. 118 (3), 489-496.

Codreanu, A. (2010). Organizational Change: A Matter Of Individual and Group Behavior Transformation, 1(1), 4956.

Corbin, J. M., \& Strauss, A. (2007). Basics of Qualitative Research: Techniques and Procedures for Developing Grounded Theory. SAGE Publications, Inc. New York.

Creswell, J. W. (2013). Research Design: Qualitative, Quantitative, and Mixed Methods Approaches. SAGE Publications, Inc. United Kingdom.

Dinas Pertanian Prov Moluccas. (2012). Prosiding : Agroforestry berbasis Pala untuk Kesejahteraan Masyarakat Moluccas. In Presentasi :Strategi Pengembangan Komoditi Pala di Moluccas (pp. 98- 104) [Proceedings: Nutmegbased Agroforestry for Moluccas People's Welfare. In Presentation: Strategy for Development of Nut Commodity in Moluccas (pp. 98- 104)]. Ambon: Program studi Manajemen Hutan PPs Universitas Pattimura Ambon, KPM \& Cordaid

Dluhosch, B., \& Horgos, D. (2008). Wage vs. industry subsidies: coping with technology related unemployment in a globalized economy. International Economics and Economic Policy, 5(4), 371-388.

Elliot, S. (2006). Technology-Enabled Innovation, Industry Transformation and the Emergence of Ambient Organizations. Industry and Innovation, 13(2), 209-225.

Fernandes, A. S. C., \& Mendes, P. M. (2003). Technology as culture and embodied knowledge. European Journal of Engineering Education, 28(2), 151-160.

Gemnafle, M., Waimuri, S. P., Batlolona, J. R. (2018). Organizational Climate of the School and Teacher Performance Improvement in the 21st Century. International Journal of Science and Research (IJSR), 7 (2), 119-128.

Gils, C. V, \& Cox, P. A. (1994). Ethnobotany of nutmeg in the Spice Islands. Journal of Ethnopharmacology, 42, 117124.

Graeber, D. (2006). Turning Modes of Production Inside Out. Critique of Anthropology, 26 (1), 61-85.

ITC., 2015. List of exporter for nutmeg, mace and cardamons. International Trade Centre (ITC). http://www.trademap.org/tradestat/Country_SelProduct_T S.aspx. 
Jaiswal \& Singh. (2009). Molluscicidal Activity of Nutmeg and Mace (Myristica Fragrans Houtt.) Against the Vector Snail Lymnaea Acuminata. Journal of Herbs, Spices \& Medicinal Plants, 15, 177-186.

Jangid K, Jayakumar ND, \& Varghese SS. (2014). Achievable therapeutic effects of Myristica fragrans (Nutmeg) on periodontitis a short review. International Journal of Pharmacy and Pharmaceutical Sciences, 6(5), 591- 594.

Kaya, M., Kammesheidt, L., \& Weidelt, H. J. (2002). The Forest Garden System of Saparua Island, Central Moluccas, Indonesia, and Its Role in Maintaining Tree Species Diversity. Agroforestry Systems, 54, 225-234.

LaForge, R. W., Ingram, T. M., \& Cravens, D. W. (2014). Strategic alignment for sales organization transformation. Journal of Strategic Marketing, 17(3-4), 199-219.

Lape, P. V. (2000). Political dynamics and religious change in the late pre-colonial Banda Islands, Eastern Indonesia. World Archaeology, 32(1), 138-155.

Laurens, T., Batlolona, F. A., Batlolona, J. R., \& Leasa, M. (2018). How Does Realistic Mathematics Education (RME) Improve Students' Mathematics Cognitive Achievement?. Eurasia Journal of Mathematics, Science and Technology Education, 14(2), 569-578.

Leasa, M. Talakua, M., Batlolona, J. R. 2016. The development of a Thematic Module Based on Numbered Heads Together (NHT) Cooperative Learning Model for elementary Students in Ambon, Moluccas-Indonesia. New Educational Review, 46(4), 174-185.

Leela, N. K. (2008). Nutmeg and mace. In V. A. Parthasarathy, B. Chempakam, \& T. J. Zachariah (Eds.), Chemistry of spices (pp. 165-189). CAB Int. London, UK.

Ma'mun. 2013. Characteristics of oil and trimyristin isolation of Papua Nutmeg seeds (Myristica argentea). Jurnal Penelitian Tanaman Industri. 9 (2), 72-77.

Moluccas dalam Angka, 2015. https://moluccas.bps.go.id/ (Diakses 5 Januari 2018)

Matinahoru, J. M. (2009). Kontribusi Pola Pertanian Dusun Bagi Ketahanan Pangan Masyarakat Moluccas [Contribution of Hamlet Agriculture System to Food Security in Moluccas]. Jurnal Agroforestri, 2(2), 79-83.

Matinahoru, J. M. (2011). Strategi Pengembangan Model Dusun sebagai Sistem Agroforestry Khusus Bagi PulauPulau Kecil di Moluccas [Development Strategy of Hamlet Model as Agroforestry System Especially in Small Islands of Moluccas]. Paper presented at the Training of Shifting Cultivation Control in Mountain Villages in Inamosol Sub-District of Seran Bagian Barat District, Nuduasiwa Development Foundation, Ambon, 10 August, 2011.

Matinahoru, J. M. (2014). A Review On Dusun As An Indigenous Agroforestry System Practiced In Small Islands. Occasional Papers (Kagoshima University Research Center For The Pacific Islands), 54, 53-60.

Miles, M., Hberman, M., \& Sdana, J. (2014). Qualitative Data Analysis: A Methods Sourcebook. Sage: Amerika Serikat. Purseglove, J.W., E.G. Brown, S.L. Green, \& Robbins, S. R. J. (1995). Spices. Longmans, New York. p. 175-228.

Robinson, W. I. (2007). Beyond the Theory of Imperialism: Global Capitalism and the Transnational State. Societies Without Borders, 2, 5-26.

Ruhnayat, A \& Martini, E. (2015). Guidance of mine cultivation in mixed garden. Research Institute for Spices and Medicinal Plants (Balitro) in Collaboration with AGFOR Sulawesi, World Agroforestry Center (ICRAF) Southeast Asia Regional Program, Bogor, Indonesia.

Rumphius GE. (1743). Herbarium Amboinense 4. J Burmann, Meinard Uytwerf, Amsterdam.

Rumyantsev, A. A. (2015). Post-industrial Technological Mode of Production: Theory, Economic and Environmental Features, Discussion Questions. International Journal of Economics and Financial Issues, 5, 194-201.

Salampessy, M. L., Febryano, I. G., \& Zulfiani, D. (2017). Bound by debt: Nutmeg trees and changing relations between farmers and agents in a Moluccan agroforestry systems. Forest and Society, 1(2), 60-66.

Sanghai-Vaijwade DN, Kulkarni SR, \& Sanghai NN. (2011). Nutmeg: a promising antibacterial agent for stability of sweets. International Journal of Research in Pharmacy and Chemistry, 1(3), 403-407.

Sirappa, M. P., \& Susanto, A. N. (2015). Opportunity and Strategy Development of Clonal Nutmeg at Moluccas, Indonesia. J. Biol. Chem. Research, 32(1), 290-298.

Tang, K. (2011). Industrial-Organization-Transformation-Oriented Agricultural Modernization with Chinese Characteristics: From the Perspective of Industrial and Agricultural Interaction. International Journal of Business and Management, (5), 211-216. 
Tausch, A. (2012). The Effects of Multinational Corporation (MNC) Penetration on the Global Political Economy. A Re-analysis of a Recurrent Sociological Proposition with Contemporary Data. Sociologia, 44(3), 314-347.

Vicol, M., Pritchard, B., \& Htay, Y. Y. (2018). Rethinking the role of agriculture as a driver of social and economic transformation in Southeast Asia's upland regions: The view from Chin State, Myanmar. Land Use Policy,72, 451460.

Winn, P. (2010). Slavery and cultural creativity in the banda islands. Journal of Southeast Asian Studies, 41(3), 365389.

Zener, C. (1994). Through a Green Lens: The Construction of Customaxy Environmental Law and Community in Indonesia's Moluccas Islands. Law \& Society Review, 28(5), 1079-1122.

Steward,J, H. (1955). Theory of Culture Change: The Methodology of Multilinear Evolution. Urbana:University of Illinois Press. 